\title{
Use of $\mathrm{N}$-methylene phosphonic chitosan to obtain an isoniazid prodrug
}

\author{
Daniela Gonçales Rando ${ }^{1}$, Carlos Alberto Brandt ${ }^{2}$, Elizabeth Igne Ferreira ${ }^{1 *}$ \\ 'Departamento de Farmácia, Faculdade de Ciências Farmacêuticas, Universidade de São Paulo, \\ ${ }^{2}$ Instituto Butantan, São Paulo
}

*Correspondence:

E. I. Ferreira

Departamento de Farmácia, Faculdade de Ciências Farmacêuticas - USP

Av. Prof. Lineu Prestes, 580

05508-900 - São Paulo - SP

E-mail: hajudan@usp.br
Tuberculosis(TB) is one of the most neglected health problems and has been out of control in many areas of the world. Since new antituberculous alternatives, including controlled classical drug delivery systems, are urgently needed to face this serious situation, the purpose of the present work was the synthesis and characterization of a prolonged action prodrug of isoniazid. The $\mathrm{N}$-methylene phosphonic chitosan (NMPC), a hydrosoluble derivative of chitosan was used as drug carrier. This analog, as well as its precursor, exhibits stimulatory activity on macrophages, host cells of Mycobacterium tuberculosis. Due to its hydrosolubility, it can be easily handled and intravenously administrated. The NMPC can be obtained by reaction of chitosan with phosphorous acid in presence of formaldehyde. Once synthesized, the coupling with isoniazid was carried out after two steps: functionalization of the drug with a succinic spacer group and activation of the succinyl isoniazid through the cyclic analog 1-(pyridine-4carbonyl)-tetrahydro-pirydazin-3,6-dione.
Uniterms:

- Chitosan

- N-methylene phosphonic chitosan

- Isoniazid

- Prodrug

\section{INTRODUCTION}

Tuberculosis (TB) remains the leading cause of death among the infectious diseases in the world. The estimated 8.8 million new cases every year correspond to 52,000 deaths per week or more than 7,000 every day, which translates into more than 1,000 new cases every hour (Rattan, Kalia, Ahmad, 1998). Figure 1 shows the epidemiological situation of tuberculosis in the world.

The resurgence of TB has been mainly attributed to HIV epidemic. Also the frequent treatment interruptions by patients due to the diminution of symptoms and drug toxicity are responsible for recidives and, most importantly, to the emergence of multidrug-resistant strains (Bloom, Rook, 1994; Fätkenheuer et al., 1999).

From this perspective, the search for new therapeutic alternatives to tuberculosis is of utmost importance. One of the recommendations of World Health Organization (1998) to tuberculosis treatment is the strategy to achieve the patient's compliance. This could be possible either by using a most potent drug in a single dosis or a drug that has prolonged action.

Molecular modification is one of the most promising processes to introduce new drugs on the market. Prodrug design is one of the processes comprehended by molecular modification that deserves most attention (Ettmayer et al., 


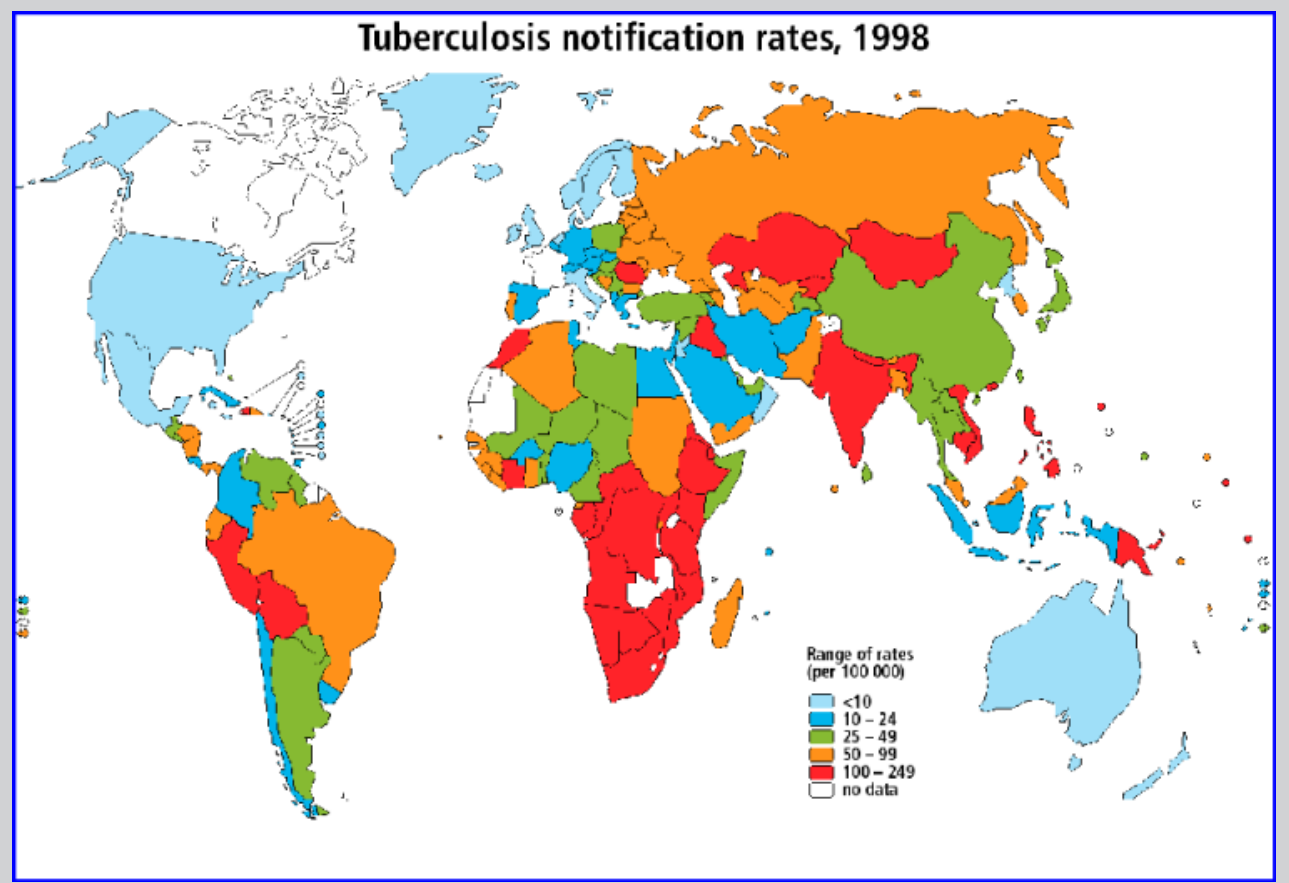

FIGURE 1 - Epidemiological distribution of TB. Source: WHO, 2000.

2004; Chung, Ferreira, 1999; Taylor, Kennewell, 1993).

Prodrug design involves a broad set of processes by which an inactive transport form is produced. In vivo, by means of enzymatic or chemical reactions (Wermuth, 2003), it releases the drug at the site of action or near it (Bundgaard, 1985; Bundgaard, 1991). Figure 2 shows a schematic representation of prodrug design.

A classical prodrug is employed with many purposes, as to improve bioavailability, obtain prolonged action, diminish toxicity, achieve high selectivity of action and solve formulation problems.

According to Wermuth (2003) other two latent forms may be basically obtained through this approach: bioprecursors and targeted drugs, being the later usually employed to obtain high level of selectivity.

The rational design of a prodrug must consider the existence of moieties, in the drug and carrier, able to suffer either specific biotransformation or non-selective one. A

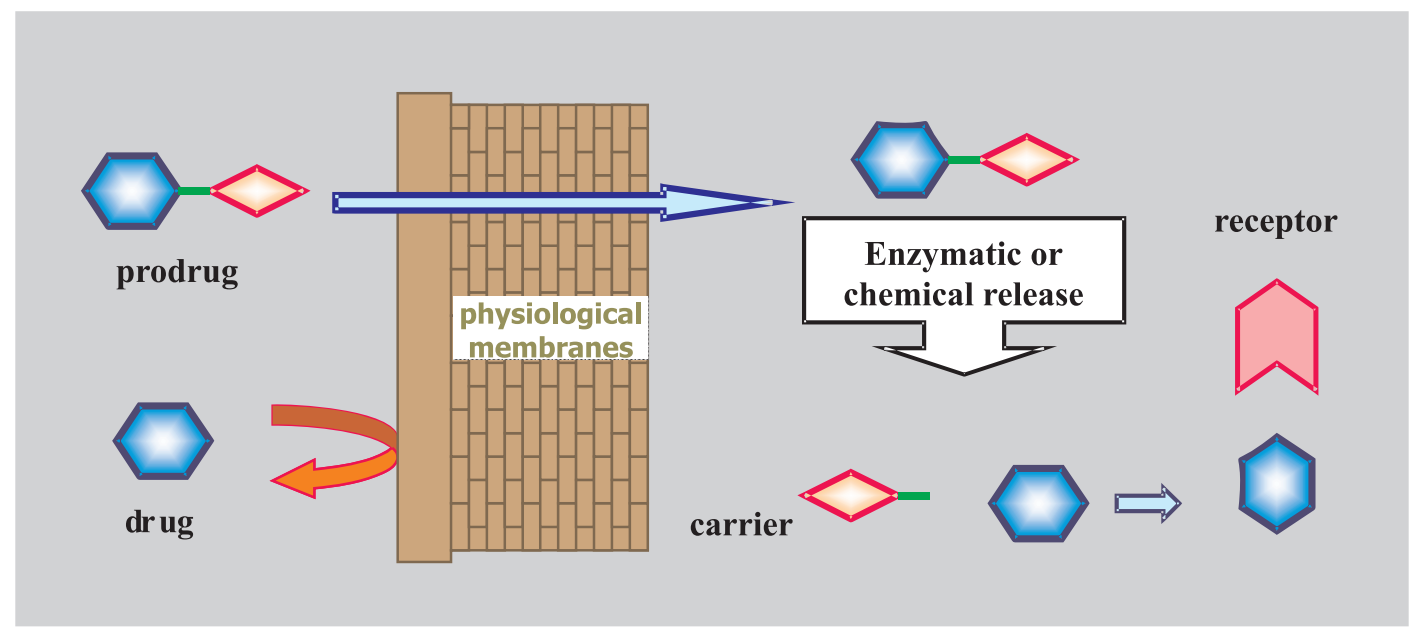

FIGURE 2 - Representation of a prodrug design to enhance bioavailability. 
broad set of carriers may be chosen depending on the objective of prodrug design (Chung, Ferreira, 1999).

Polymers are useful as drug carriers in order to optimize drug delivery owing to their suitable physicochemical and biological properties. Those carriers are, frequently, used to prolong the action of drugs that must be administered for a long period of time (KrogsgaardLarsen, Liljefors, Madsen, 1996; Schacht, Vansteenkiste, Seymour,1996).

The polymers are either directly or through a spacer covalently linked to the drug, that guarantee slow and gradual release. Spacers are groups are those without biologic activity that due to their strength and flexibility can be used to facilitate the release of the drug. They also provide the accessibility of enzymes to the linkage (Chung, Ferreira, 1999).

Polymer carriers can be natural or synthetic. Among the natural polymers, polysaccharides, such as dextran, have been widely used (Schacht, Vansteenkiste, Seymour,1996). More recently, two polysaccharides have deserved attention - chitin and chitosan (Muzzarelli, Muzzarelli, 2002). Chitin is a widely available biopolymer extracted from shrimp and crab shells, which is a copolymer of $\beta 1 \rightarrow 4$-D-glucosamine and $\beta 1 \rightarrow 4-N$-acetylD-glucosamine with variable composition. Chitosan, a partially deacetylated form of chitin, contains free amine groups, which can be used as sites for drug attachment (Hirano et al., 1990).

A wide range of applications for chitosan includes wastewater treatment, food, agriculture, cosmetic and personal care, biotechnology and pharmaceutical areas. Onishi et al. (1996) reported the use of chitosan as drug carrier in the development of mitomycin $\mathrm{C}$ prodrugs.

Generally, chitosan is the most used carrier because of the presence of free $\mathrm{NH}_{2}$ group that provides a reactional center either to modification or drug linkage. This derivative is almost atoxic $\left(\mathrm{LD}_{50}=16\right.$ g. $\mathrm{kg}^{-1}$ p.o. in rats) and has immunopotentiating effect by stimulating macrophages and increasing the humoral response (Shibata, Metzger, Myrvik, 1997; Zang et al., 1995). However, the aqueous solubility of chitosan depends on the degree of protonation of the $\mathrm{NH}_{2}$ group by acid treatment, which limits its versatility (Shigemasa et al., 1999). This is particularly important in the case of chitosan with high degree of deacetylation.

One reason for the difficulty in working with these polymer lies in the rigid crystalline structure and in the acetamide or primary amine group residues that have an important role in the formation of conformational features through intra and/or intermolecular hydrogen bonding (Hirano et al., 1990).
Many efforts have been made to prepare water soluble derivatives from chitosan (Zong et al., 2000). Acylated (Kubota et al., 2000), sulphonated or sulphated (Nishimura et al., 1998) derivatives have been synthesized with good degrees of aqueous solubility.

Replacing the two hydrogens of the free amino group by hydrophilic groups results in aqueous solubility improvement. Based on this purpose, Heras et al. (2001) suggested the synthesis of a new chitosan derivative - the $N$-methylene phosphonic chitosan (NMPC) (Figure 3).

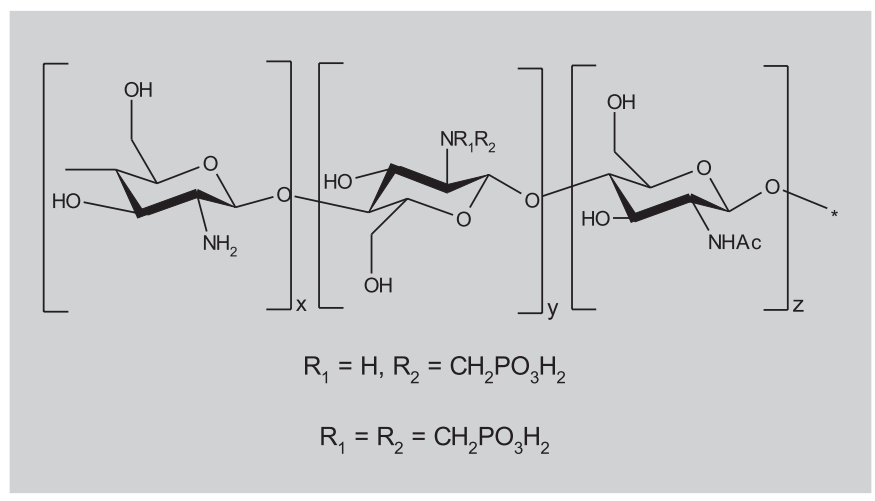

FIGURE 3 - $N$-methylene phosphonic chitosan mono and disubstituted.

This compound showed an immediate solubility in water, and in other aqueous systems as $1 \% \mathrm{NaOH}$ and $1 \%$ acetic acid.

According to the serious situation of TB and considering the above described, our purpose was the design and synthesis of a new macromolecular prodrug of isoniazid (INH) with prolonged action. Isoniazid was chosen since it is the most potent drug used in the current therapeutics of TB. Also, it has been used as a prophylactic agent, for six months, in tuberculin positive individuals (Iseman, 1999). The $N$-methylene phosphonic chitosan derivative was used to obtain a hydrosoluble prodrug. Due to its immunostimulating macrophage properties, we believe that the activity of such prodrug against Mycobacterium tuberculosis could be enhanced since they are the most infected cells in the host.

\section{MATERIAL AND METHODS}

\section{Material}

Chitosan was provided by Prof. Marconi Ginani from Universidade Federal do Rio Grande do Norte, with deacetylation degree of $80 \%$ estimated by infrared and confirmed by Nuclear Magnetic Resonance (NMR). Molecular weight of $1.8 \times 10^{5}$ was determined by 
measurements of viscosity in reometer and application of Mark-Howink equation.

Isoniazid used was from FURP - Fundação para o Remédio Popular, succinic anhydride from Merck, phosphorous acid from Aldrich, thionyl chloride from Fluka and dialysis tubing (cut off MW 12.000-14.000) from Sigma. All other reagents (solvents and salts) of analytical grade were from Merck.

\section{Apparatus}

The ${ }^{1} \mathrm{H}$ NMR and ${ }^{13} \mathrm{C}$ NMR spectrometry were carried out on a NMR spectrometer Bruker ADPX, $300 \mathrm{MHz}$; chemical shifts are reported in ppm downfield from internal or external TMS reference. The solvents used were DMSO- $\mathrm{d}_{6}, \mathrm{D}_{2} \mathrm{O}$ and $\mathrm{CDCl}_{3}$. Acquisition was obtained at $70{ }^{\circ} \mathrm{C}$ to all polymeric derivatives and at $25^{\circ} \mathrm{C}$ to other compounds. Infrared spectra were obtained in a Bomem FTIR spectrophotometer, in $\mathrm{KBr}$ cells. Lyophilization was performed on a Lamedid series a1-2 device, in case of polymers purified by dialysis.

\section{General Synthetic Methods}

The synthesis of the $N$-methylene phosphonic derivative 1 was performed according to the literature (Heras et al., 2001), as shown in Scheme 1.

One equivalent of phosphorous acid in water was added dropwise to one equivalent (w/w) of $2 \%$ chitosan solution in acetic acid with continuous stirring for $1 \mathrm{~h}$. Then the temperature of the reaction vessel was raised to $70{ }^{\circ} \mathrm{C}$ and one part of $36.5 \%(\mathrm{w} / \mathrm{w})$ formaldehyde was added drop-wise over $1 \mathrm{~h}$ with reflux. Heating was protracted for $6 \mathrm{~h}$ at the same temperature. The clear pale yellow solution was dialyzed against demineralized water for $48 \mathrm{~h}$ or until the $\mathrm{pH}$ of water was raised to 6.8 in dialysis tubing with a cut-off of $2500 \mathrm{Da}$. Finally, the solution was frozen and freeze-dried.

Succinyl isoniazid 2 was obtained from reaction of succinic anhydride with isoniazid, in chloroform, at $70^{\circ} \mathrm{C}$ for 4 hours, or in THF in ultrasound for 40 minutes (Scheme 2).

This compound was cyclized by reaction with thionyl chloride at room temperature as showed in Scheme 3.

From this cyclisation, rings of five or six members (compounds $\mathbf{3}$ or $\mathbf{3}$ ' in the Scheme 3 ) could be obtained.

Prodrug 4 was, finally, obtained by reaction between the cyclic derivative 3 (and/or 3') (1 mmol) with the $N$ methylene phosphonic chitosan (1) (1 mmol of free $\mathrm{OH}$ ) and $1 \mathrm{mmol}$ of pyridine in $\mathrm{N}, \mathrm{N}$-dimethylformamide under stirring at $90^{\circ} \mathrm{C}$ for 30 hours (Scheme 4).

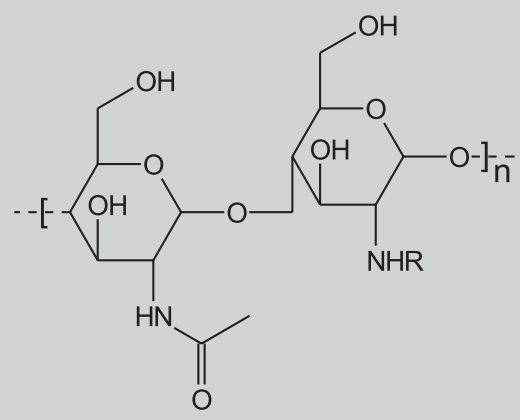

$2 \%$ glacial acetic acid sol. (v/v)

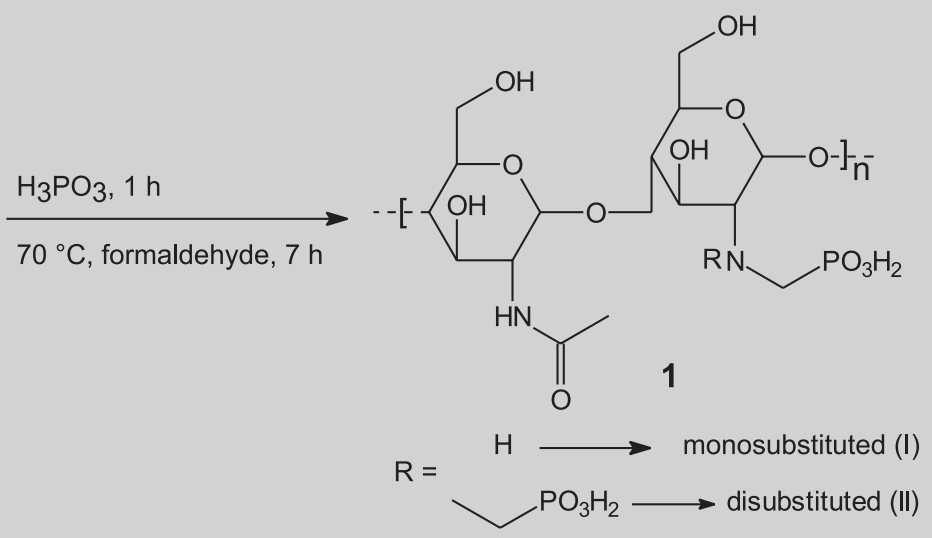

SCHEME 1 - Synthesis of $N$-methylene phosphonic derivative (NMPC).

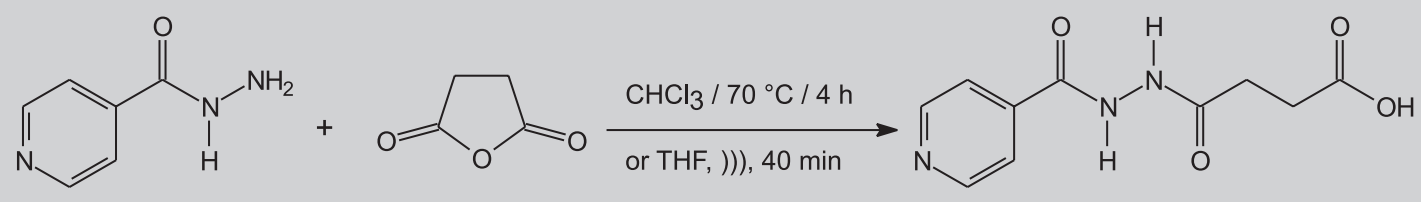

SCHEME 2 - Synthesis of succinyl isoniazid. 


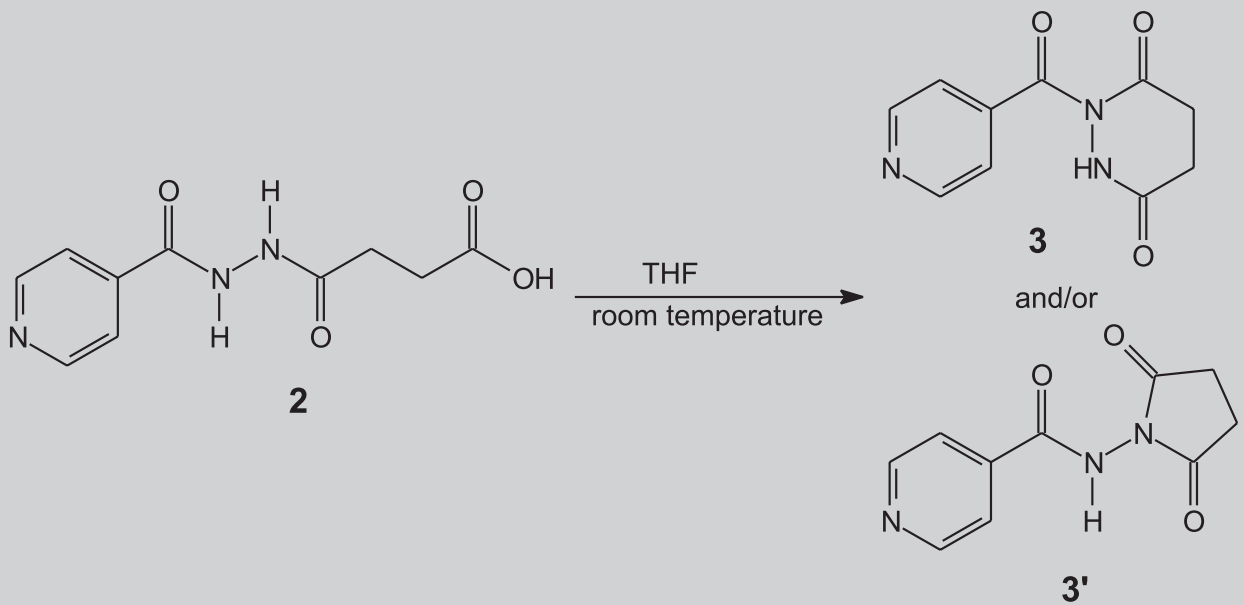

SCHEME 3 - Cyclisation of succinyl isoniazid.

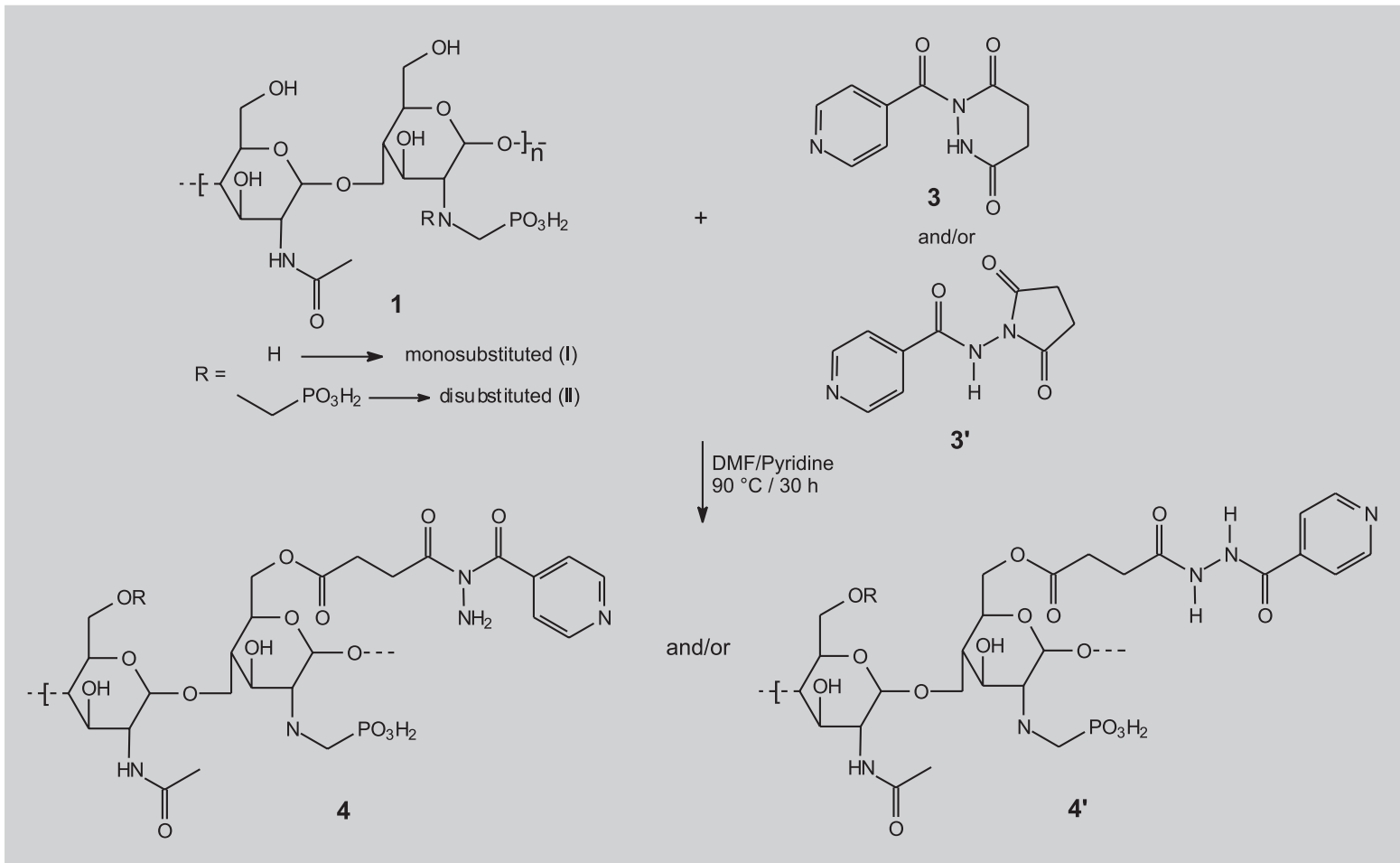

SCHEME 4 - Synthesis of NMPC-INH prodrug.

\section{RESULTS AND DISCUSSION}

Analytical data of 1-4 compounds are presented bellow.

N-methylene phosphonic chitosan (1) - Following the general procedure, $1.05 \mathrm{~g}$ (from $0.5 \mathrm{~g}$ of chitosan)** of an amorphous pale yellow product was obtained. ${ }^{1} \mathrm{H}-\mathrm{NMR}$ (300 MHz, $\left.\mathrm{D}_{2} \mathrm{O}, \mathrm{ppm}\right): 2.00\left(3 \mathrm{H}, \mathrm{s}, \mathrm{H}_{10}\right), 2,70(2 \mathrm{H}, \mathrm{s}$, $\left.\mathrm{H}_{7}(\mathrm{II} *)\right), 3.40-3.66\left(4 \mathrm{H}, \mathrm{m}, \mathrm{H}_{7}\left(\mathrm{I}^{*}\right), \mathrm{H}_{2}(\mathrm{I}), \mathrm{H}_{2}(\mathrm{II})\right), 4.31-$ $4.58\left(3 \mathrm{H}, \mathrm{m}, \mathrm{H}_{3}-\mathrm{H}_{6}\right), 5.24\left(1 \mathrm{H}, \mathrm{s}, \mathrm{H}_{1}(\mathrm{I})\right), 5.56(1 \mathrm{H}, \mathrm{s}$, $\left.\mathrm{H}_{1}(\mathrm{II})\right), 6.43\left(2 \mathrm{H}, \mathrm{s}, \mathrm{H}_{11}\right), 8.51\left(1 \mathrm{H}, \mathrm{s}, \mathrm{H}_{9}\right)$.

I* = monosubstituted, II* = disubstituted; ** Since the chitosan molecular weight could not be determined in our laboratory, the yield in percentage was not calculated.

To standard chemical shifts see Shigemasa et al. (1999) and Heras et al. (2001).

Succinyl Isoniazid (2) - By applying the procedure early described, a white powder was obtained in good 
yields $92.4 \%$ (reflux in chloroform) and $80.99 \%$ (ultrasound reaction).

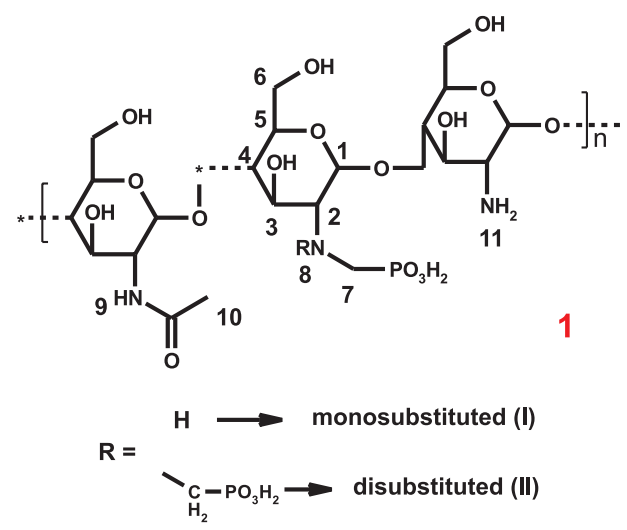

${ }^{1} \mathrm{H}-\mathrm{NMR}$ (300 MHz, $\left.\mathrm{D}_{2} \mathrm{O}, \mathrm{ppm}\right):$ 2.70-2.78 (4H, m, $\mathrm{H}_{11}$ and $\left.\mathrm{H}_{12}\right), 7.96\left(2 \mathrm{H}, \mathrm{d}, \mathrm{H}_{3}\right.$ and $\left.\mathrm{H}_{5}\right), 8.84\left(2 \mathrm{H}, \mathrm{d}, \mathrm{H}_{2}\right.$ and $\mathrm{H}_{6}$ ). ${ }^{1} \mathrm{H}-\mathrm{NMR}(300 \mathrm{MHz}, \mathrm{DMSO}, \mathrm{ppm}): 7.78\left(2 \mathrm{H}, \mathrm{d}, \mathrm{H}_{3}\right.$ and $\left.\mathrm{H}_{5}\right), 8.77\left(2 \mathrm{H}, \mathrm{d}, \mathrm{H}_{2}\right.$ and $\left.\mathrm{H}_{6}\right), 10.06\left(1 \mathrm{H}, \mathrm{s}, \mathrm{H}_{9}\right), 10.66$ $\left(1 \mathrm{H}, \mathrm{s}, \mathrm{H}_{8}\right), 11.74\left(1 \mathrm{H}, \mathrm{s}, \mathrm{H}_{14}\right) \cdot{ }^{13} \mathrm{C}-\mathrm{NMR}\left(75 \mathrm{MHz}, \mathrm{D}_{2} \mathrm{O}\right.$, ppm): 28.05 and $28.66\left(\mathrm{C}_{11}\right.$ and $\left.\mathrm{C}_{12}\right), 121.23\left(\mathrm{C}_{3}\right.$ and $\left.\mathrm{C}_{5}\right), 139.42\left(\mathrm{C}_{4}\right), 150.30\left(\mathrm{C}_{2}\right.$ and $\left.\mathrm{C}_{6}\right), 163.82\left(\mathrm{C}_{7}\right), 170.39$ $\left(\mathrm{C}_{10}\right), 173.44\left(\mathrm{C}_{13}\right)$. IR $\left(\mathrm{KBr}, \mathrm{cm}^{-1}\right): 3214(\mathrm{vN}-\mathrm{H}), 1708$ ( $\vee \mathrm{C}=\mathrm{O}$ acid $), 1608(\mathrm{vC}=\mathrm{O}$ hydrazide and amide),1500 $(v \mathrm{~N}-\mathrm{C}=\mathrm{O}), 1474-1411$ ( $v \mathrm{C}-\mathrm{N}$ e $\mathrm{HC}=\mathrm{CH}$ aromatic $)$.

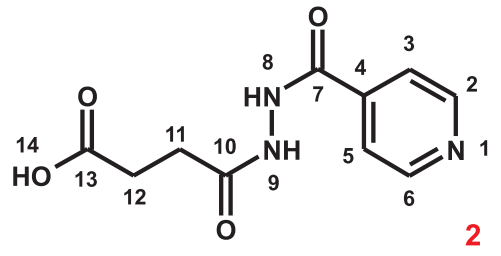

1-(pyridine-4-carbonyl)-tetrahydro-pirydazin3,6-dione (3): Stirring succinyl isoniazid with thionyl chloride a white powder $(72 \%)$ was obtained. ${ }^{1} \mathrm{H}-\mathrm{NMR}$ (300 MHz, $\left.\mathrm{D}_{2} \mathrm{O}, \mathrm{ppm}\right): 2.80-2.95\left(4 \mathrm{H}, \mathrm{m}, \mathrm{H}_{11}\right.$ and $\left.\mathrm{H}_{12}\right)$, $8.39\left(2 \mathrm{H}, \mathrm{d}, \mathrm{H}_{3}\right.$ and $\left.\mathrm{H}_{5}\right), 9.03\left(2 \mathrm{H}, \mathrm{d}, \mathrm{H}_{2}\right.$ and $\left.\mathrm{H}_{6}\right)$.

${ }^{1} \mathrm{H}-\mathrm{NMR}(300 \mathrm{MHz}, \mathrm{DMSO}, \mathrm{ppm}): 8.15\left(2 \mathrm{H}, \mathrm{d}, \mathrm{H}_{3}\right.$ and $\left.\mathrm{H}_{5}\right), 8.99\left(2 \mathrm{H}, \mathrm{d}, \mathrm{H}_{2}\right.$ and $\left.\mathrm{H}_{6}\right), 10.23\left(1 \mathrm{H}, \mathrm{s}, \mathrm{H}_{9}\right), 11.02$ $\left(1 \mathrm{H}, \mathrm{s}, \mathrm{H}_{1}\right) \cdot{ }^{13} \mathrm{C}-\mathrm{NMR}(75 \mathrm{MHz}, \mathrm{DMSO}, \mathrm{ppm}): 28.03$ and $28.65\left(\mathrm{C}_{11}\right.$ and $\left.\mathrm{C}_{12}\right), 123.56\left(\mathrm{C}_{3}\right.$ and $\left.\mathrm{C}_{5}\right), 143.99\left(\mathrm{C}_{4}\right)$, $145.83\left(\mathrm{C}_{2}\right.$ and $\left.\mathrm{C}_{6}\right), 162.30\left(\mathrm{C}_{7}\right), 170.28\left(\mathrm{C}_{10}\right), 173.39$
$\left(\mathrm{C}_{13}\right) \cdot \operatorname{IR}\left(\mathrm{KBr}, \mathrm{cm}^{-1}\right): 3179(v \mathrm{~N}-\mathrm{H}), 1727\left(v \mathrm{C}=\mathrm{O} \mathrm{C}_{10}\right)$, $1605\left(\nu \mathrm{C}=\mathrm{O} \mathrm{C}_{7}\right.$ and $\left.\mathrm{C}_{13}\right), 1513-1407(\nu \mathrm{C}-\mathrm{N}$ and $\mathrm{HC}=\mathrm{CH}$ aromatic $)$.<smiles>O=C1CCC(=O)N(C(=O)c2cc[nH+]cc2)N1</smiles>

Chitosan-Isoniazid hemisuccinate (4) - The potential prodrug was obtained as a pale brown solid $(0,021 \mathrm{~g}$ from $0,039 \mathrm{~g}$ of 1$) .{ }^{1} \mathrm{H}-\mathrm{NMR}\left(300 \mathrm{MHz}, \mathrm{D}_{2} \mathrm{O}\right.$, ppm): $1.98\left(3 \mathrm{H}, \mathrm{s}, \mathrm{H}_{8}\right), 2.70-2.80\left(4 \mathrm{H}, \mathrm{m}, \mathrm{H}_{9}, \mathrm{H}_{10}\right), 3.18-$ $3.66\left(3 \mathrm{H}, \mathrm{m}, \mathrm{H}_{7}, \mathrm{H}_{2}\right), 4.25-4.59\left(3 \mathrm{H}, \mathrm{m}, \mathrm{H}_{3}-\mathrm{H}_{6}\right), 5.26$ $\left(1 \mathrm{H}, \mathrm{s}, \mathrm{H}_{1}(\mathrm{I})\right), 5.57\left(1 \mathrm{H}, \mathrm{s}, \mathrm{H}_{1}(\mathrm{II})\right), 8.46\left(2 \mathrm{H}, \mathrm{d}, \mathrm{H}_{11}\right.$ and $\left.\mathrm{H}_{14}\right), 9.41\left(2 \mathrm{H}, \mathrm{d}, \mathrm{H}_{12}\right.$ and $\left.\mathrm{H}_{13}\right)$.

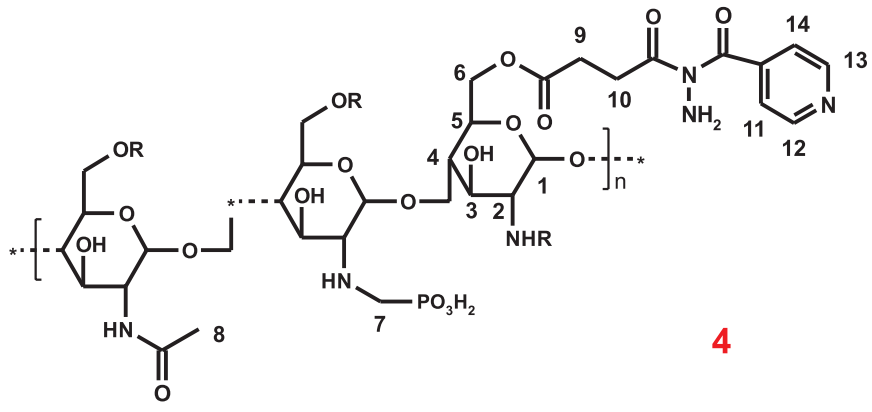

The $N$-methylene phosphonic derivative from chitosan 1 was obtained in good yield $(1.05 \mathrm{~g})$ being, immediately, soluble in water.

Chemical shifts at $\delta 5.24$ and 5.56 were attributed to $\mathrm{H}_{1}$ of monossacharidic ring, respectively, from chitosan monosubstituted (I) and disubstituted (II) in $\mathrm{NH}_{2}$ moiety.

According to Heras et al. (2001), the yield of those derivatives can be estimated by the rates between their respective integrals (Table I).

Signs in $\delta 6.43$ and 8.51 were attributed to amine and amide hydrogens, respectively.

Succinyl isoniazid was obtained in 4 hours $(92.4 \%)$. NMR and IR analyses of the acid $\left(1708 \mathrm{~cm}^{-1}, v \mathrm{C}=\mathrm{O}\right.$ and $\delta$ 173.44), from hydrazide and from amide groups $\left(1608 \mathrm{~cm}^{-1}, v \mathrm{C}=\mathrm{O}\right.$ and $\delta 163.82$ and 170.39 , respectively)

TABLE I - Rate between NMPC monosubstituted and disubstituted.

\begin{tabular}{lcccc}
\hline $\boldsymbol{\delta}(\mathbf{p p m})$ & Derivative & Integral & $\mathbf{\Sigma} \mathbf{H}_{\mathbf{1}}=\mathbf{1 0 0} \%$ & $\mathbf{\%}$ \\
\hline 5.24 & monosubstituted & 0,6 & 0,9 & 66.67 \\
5.56 & disubstituted & 0,3 & & 33.33 \\
\hline
\end{tabular}


have initially confirmed its structure. The structure was definetely confirmed by X-Ray spectrometry (Doriguetto et al., 2003). The cyclic derivative was obtained just for stirring the succinyl isoniazid with thionyl chloride for 9 hours. The purpose was to synthesize an acid chloride which suffers cyclisation by nucleophilic attack of one of the two nitrogens atoms from hydrazide moiety to carbonyl group, producing the corresponding succinimide hydrochloride. However, some questions have arisen from ${ }^{1} \mathrm{H}$ and ${ }^{13} \mathrm{C}$ NMR spectra analyses of compounds $\mathbf{2}$ and $\mathbf{3}$ (or 3'), due to their high structural similarity. Only slightly differences in chemical shifts have been identified. This could be observed because compound 3 was in its respective hydrochloride salt form.

On the other hand, cyclisation could generate cycles of five (3') or six (3) members depending on which of the two reactive nitrogens of succinyl hydrazide has been involved in the nucleophilic attack (Scheme 3).

The infrared spectrum has suggested structural differences between the compound $\mathbf{2}$ and the product of the reaction with thionyl chloride. A band at $1708 \mathrm{~cm}^{-1}$ was related to acid carbonyl stretching of succinyl isoniazid. This band was not observed in the cyclic derivative, as a band at $1727 \mathrm{~cm}^{-1}$ could be attributed to carbonyl group stretching of cyclic moiety.
To prove that the cyclic derivative has been obtained, the 2-D HMBC experiment with $\mathrm{J}_{2}$ at $5 \mathrm{~Hz}$ to the compounds $\mathbf{2}$ and the compound $\mathbf{3}$ (or $\mathbf{3}^{\prime}$ ) was performed (Figure 4).

At first, the chemical shifts of the carbonyl groups of the starting material were determined by ${ }^{1} \mathrm{H}-\mathrm{NMR}$. The hydrazide carbonyl group was identified with $\delta$ around 160 . This is in accordance with the reported value to isoniazid $(\delta 160)$. The acid carbonyl group resonates at $170 \mathrm{ppm}$ as well as the amide carbonyl. But, the former has the most deprotected carbonyl groups, and for this very reason, its chemical shift is higher than the others.

The NMR spectrum obtained to succinyl isoniazid 2 showed that hydrogens from nitrogens 8 and 9 are coupling with carbonyl carbons $\mathrm{C}_{7}$ and $\mathrm{C}_{10}$, respectively (Figure 4). In addition, it was possible to identify the correlations between the carbons $\mathrm{C}_{10}$ and $\mathrm{C}_{13}$, respectively, with the hydrogens $\mathrm{H}_{11}$ and $\mathrm{H}_{12}$.

To the cyclic derivative, coupling between the hydrogen $\mathrm{H}_{9}$ and the carbon $\mathrm{C}_{10}$ was detected (Figure 5). The sign at $11.02 \mathrm{ppm}$ is not coupling with any carbon on spectrum. Thus, it was attributed to the hydrogen of the hydrochloride form of pyridine ring.

The spectrum shows the presence of three different carbonyl groups what could be possible in the formation of

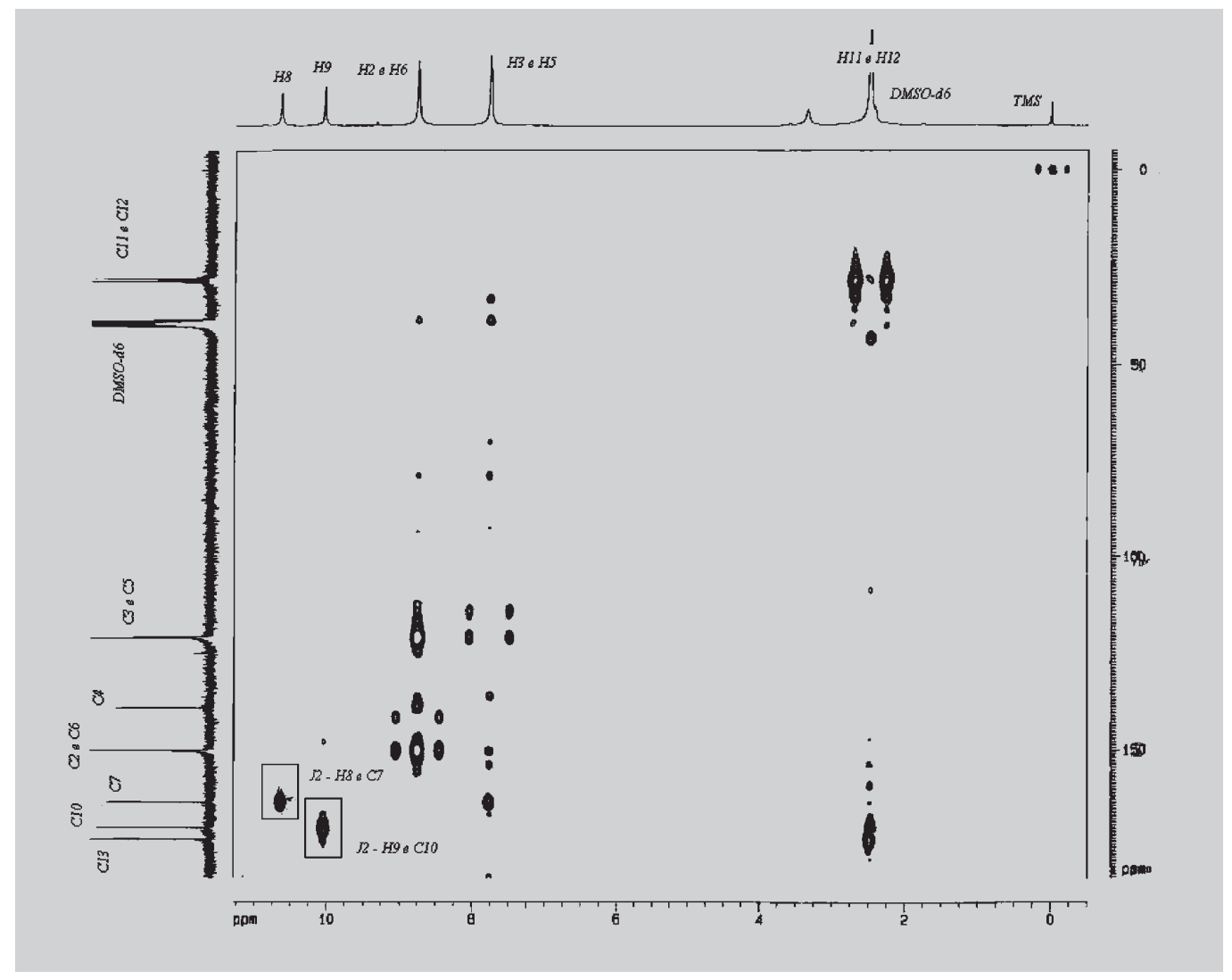

FIGURE 4 - Compound $2 \mathrm{HMBC}$ with $\mathrm{J}_{2}$ at $5 \mathrm{~Hz}$. 


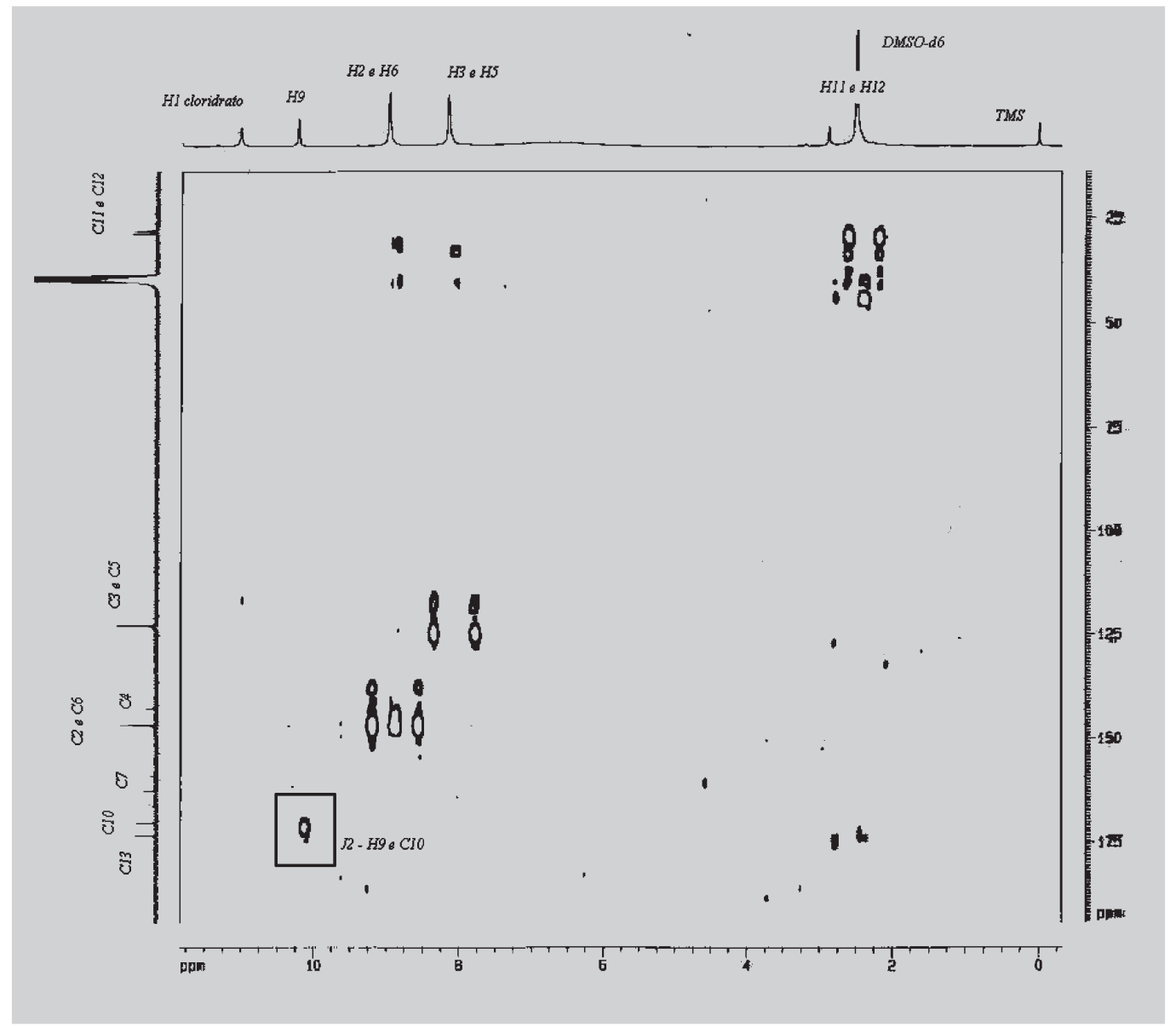

FIGURE 5 - Compound 3 , $\mathrm{HMBC}$ with $\mathrm{J}_{2}$ at $5 \mathrm{~Hz}$.

six-membered derivative which is an asymmetrical structure (Figure 6). From the same reason, the obtention of six-membered analog is confirmed by the presence of two chemical shifts to the carbon $\mathrm{C}_{11}$ and $\mathrm{C}_{12}$ which should be different if the six-membered analog had been obtained.

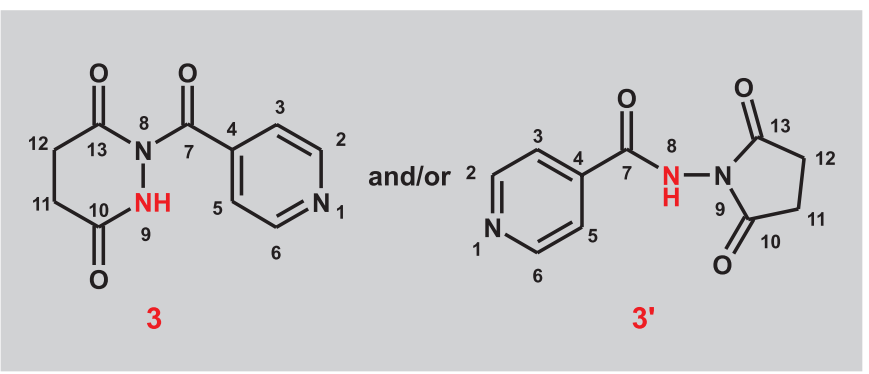

FIGURA 6 - Two possible derivatives obtained from succinyl isoniazid cyclisation.

Finally, the prodrug was synthesized by reaction between the NMPC with the cyclic derivative. A pale yellow solid $(0.021 \mathrm{~g})$ readily soluble in water was produced. The ${ }^{1} \mathrm{H}-\mathrm{NMR}$ spectrum has confirmed the structure of the obtained product $\left(\mathrm{H}_{11} \mathrm{e} \mathrm{H}_{14}, \delta 8.46 ; \mathrm{H}_{12}\right.$ and $\mathrm{H}_{13}, \delta 9.41$ ).

This prodrug will be submitted to in vitro test in $M$. tuberculosis culture.

\section{RESUMO}

\section{Uso da $N$-metilenofosfonoquitosana para obter pró-fármaco de isoniazida}

Em 1993, a Organização Mundial de Saúde declarou a tuberculose como emergência global, considerandose a gravidade do desenvolvimento mundial da doença. Face à necessidade de alternativas quimioterápicas contra a tuberculose, especialmente em razão do aparecimento de formas multi-resistentes do Mycobacterium tuberculosis, o objetivo do presente trabalho foi a sintese e caracterização de pró-fármaco de ação prolongada de isoniazida. Para tanto, utilizouse como transportador derivado hidrossolúvel de 
quitosana-a N-metilenofosfonoquitosana (NMPC). Este derivado, bem como seu precursor, exibe atividade estimuladora de macrófagos, célula hospedeira do $\mathrm{M}$. tuberculosis. Por ser hidrossolúvel, este polímero é manuseado mais facilmente e pode ser administrado intravenosamente. O NMPC foi obtido da reação da quitosana com ácido fosforoso em presença de formaldeido. $O$ acoplamento com a isoniazida foi realizado em três etapas: funcionalização com um espaçante succínico, ativação do produto succinoilado por meio de endociclização, que resulta na formação do análogo 1-(piridina-4-carbonil)tetraidropiridazin-3,6-diona, e o acoplamento com o polímero propriamente dito.

UNITERMOS: Quitosana. N-metilenofosfonoquitosana. Isoniazida. Pró-fármacos.

\section{ACKNOWLEDGMENTS}

To FAPESP, for Master scholarship to Daniela Gonçales Rando (Process 99/07627-0), and to CAPES, for her PhD scholarship.

\section{REFERENCES}

BLOOM, B.R.; ROOK G. A. W. Mechanisms of pathogenesis in tuberculosis. In: BLOOM, B. R., Ed. Tuberculosis: pathogenesis, protection and control, Washington: ASM Press, 1994. p.3-11.

BUNDGAARD, H., Ed. Design of prodrugs. Amsterdam: Elsevier, 1985.

BUNDGAARD, H., Novel chemical approaches in prodrug design. Drugs Fut., Barcelona, v.16, n. 5, p. 443-453, 1991.

CHUNG, M.C.; FERREIRA, E.I., O processo de latenciação no planejamento de fármacos. Quím. Nova, São Paulo, v. 22, n.1, p.75- 84, 1999.

DORIGUETTO, A. C.; SILVA, C.H.T.D.; RANDO, D. G.; FERREIRA, E. I.; ELLENA, J. A. 4-(2Isonicotinoylhydrazino)-4-oxobutanoic acid. Acta Crystallogr. E, v.59, p.288-289, 2003.

ETTMAYER, P.; AMIDON, G. L.; CLEMENT, B.; TESTA,B. Lessons learned from marketed and investigational prodrugs. J. Med. Chem., Washington, v. 47, p.2393-2404, 2004.
FÄTKENHEUER, G.; TAELMAN, H.; LEPAGE, P.; SCHWENK, A.; WENZEL, R. The return of tuberculosis. Diagn. Microbiol. Infect Dis., Amsterdam, v. 34, p. 139-146, 1999.

HERAS, A.; RODRÍGUEZ, N.M.; RAMOS, V.M.; AGULLÓ, E. $N$-methylene phosphonic chitosan: a novel soluble derivative. Carbohydr. Polym., Amsterdam, v. 44, p. 1-8, 2001.

HIRANO, S.; SEINO, H.; AKIYAMA, Y.; NONAKA, I. Chitosan: A biocompatible material for oral and intravenous administrations. Progress in Biomedical Polymers. New York: Plenum Press, 1991. p. 283-290.

ISEMAN, M. Management of multidrug-resistant tuberculosis. Chemotherapy, Basel, v.45, suppl. 2, p. 3$11,1999$.

KUBOTA, N.; TATSUMOTO N.; SANO T.; TOYA K. A simple preparation of half $\mathrm{N}$-acetylated chitosan highly soluble in water and aqueous organic solvents. Carbohydr. Res., Amsterdam, v.324, p.268-274, 2000.

KROGSGAARD-LARSEN， P.; LILJEFORS，T.; MADSEN, U. Eds., A textbook of drug design and development. 2. ed. Harwood: Academic Publishers, $1996.543 \mathrm{p}$.

MUZZARELLI, R. A. A.; MUZZARELLI, C. Eds. Chitosan in pharmacy and chemistry. Grottammari: Atec, 2002. 524 p.

NISHIMURA, S.; KAI H.; SHINADA, K.;YOSHIDA, T.; TOKURA, S.; KURITA, K.; NAKASHIMA, H.; YAMAMOTO, N.; URYU,T. Regioselective syntheses of sulfated polysaccharides: specific anti-HIV-1 activity of novel chitin sulfates. Carbohydr. Res., Amsterdan. v. 306, p. 427-433, 1998.

RATTAN, A.; KALIA, A.; AHMAD, N. Multidrug-resistant Mycobacterium tuberculosis: molecular perspectives. Emerg. Inf. Dis., Atlanta, v.4, p.195-208, 1998.

SATO, M.; ONISHI, H.; KITANO, M.; YOSHIHARU, M.; NAGAI, T. Preparation and drug release characteristics of the conjugates of mitomycin $\mathrm{C}$ with glycol-chitosan and $N$-succinyl-chitosan. Biol. Pharm. Bull., Tóquio, v.19, n.2, p. 241-245, 1996. 
SCHACHT, E.H.; VANSTEENKISTE, S.; SEYMOUR, L. Macromolecular carriers for drug targeting. In: WERMUTH, C.G., Ed. The practice of medicinal chemistry. London: Academic Press, 1996. p. 717-738.

SHIBATA, Y.; METZGER, W. J.; MYRVIK, Q. N. Chitin particle-induced cell-mediated immunity is inhibited by soluble mannan: mannose receptor-mediated phagocytosis initiates IL-12 production. J. Immunol., Baltimore, v.159, p.2462-2467, 1997.

SHIGEMASA, Y.; USUI, H.,; MORIMOTO, M.; SAIMOTO, H.; OKAMOTO, Y.;MINAMI, S.; SASHIWA, H. Chemical modification of chitin and chitosan: preparation of partially deacetylated chitin derivatives via a ring-opening reaction with cyclic acid anhydrides in lithium chloride/ $N, N$-dimethylacetamide. Carbohydr. Polym., Amsterdam, v.39, p.237- 243, 1999.

TAYLOR, J. B.; KENNEWELL, P.D. Modern medicinal chemistry. Chichester: Ellis Horwood, 1993. 290 p.

WERMUTH, C.G. Designing prodrugs and bioprecursors. In: , ed. The practice of medicinal chemistry. London:

Academic Press, 2003. p. 561-586.
WORLD HEALTH ORGANIZATION. Global tuberculosis control. Tuberculosis handbook. Genebra, 1998.

WORLD HEALTH ORGANIZATION. Global tuberculosis control. WHO report 2000, Genebra, 2000.

ZANG, Y.; BROSER, M.; COHEN, H.; BODKIN, M.; LAW, K.; REIBMAN, J.; ROM, W.N. Enhanced interleukin-8 release and gene expression in macrophages after exposure to Mycobacterium tuberculosis and its components. J. Clin. Invest., New Haven, v.95, p. 586$592,1995$.

ZONG, Z.; KIMURA, Y.; TAKAHASHI, M.; YAMANE, $\mathrm{H}$. Characterization of chemical and solid state structures of acylated chitosans. Polymer, Amsterdam, v. 41, p.899$906,2000$.

Recebido para publicação em 30 de março de 2004. Aceito para publicação em 30 de junho de 2004. 